\title{
Вплив вагітності, ускладненої прееклампсією, на основні параметри центральної і периферичної гемодинаміки та показники об'ємів водних секторів організму
}

\author{
О.М. Клигуненко, О.О. Марзан \\ Дніпровський державний медичний університет, Дніпро, Україна
}

\begin{abstract}
Анотація. У статті розглянуто питання впливу вагітності, ускладненої прееклампсією, на основні параметри центральної та периферичної гемодинаміки, а також показники об'ємів водних секторів організму, у порівнянні з нормальним перебігом вагітності. У дослідження включено 120 жінок, розподілених на три групи: здорові невагітні жінки фертильного віку; вагітні з неускладненою вагітністю терміном 34-40 тиж; жінки, вагітність яких ускладнена прееклампсією середнього та тяжкого ступеня. Методом неінвазивної біоімпедансометрії комплексом моніторингу кардіореспіраторної системи і гідратації тканин проводили оцінку центральної та периферичної гемодинаміки і визначали показники водних секторів організму. Результати дослідження продемонстрували, що для неускладненої вагітності характерні еукінетичний тип гемодинаміки, помірне збільшення загального об'єму рідини, тоді як прееклампсія формує дисоціативний тип кровообігу, на фоні якого порушується перерозподіл рідини з розвитком набрякового синдрому.

Ключові слова: вагітність, прееклампсія, біоімпедансометрія, гемодинаміка, водні сектори.
\end{abstract}

\section{Вступ}

У період вагітності в організмі жінки відбуваються суттєві зміни, які стосуються практично всіх органів та систем [1, 2]. Серцево-судинна система функціонує з підвищеним навантаженням. Так, з боку центральної гемодинаміки відмічається збільшення об'єму циркулюючої крові (ОЦК) і в термін 36 тиж вагітності збільшення становить 35-45\%, в основному за рахунок об'єму плазми (ОП) [3]. Хвилинний об'єм крові (ХОК) збільшується на 30-40\%, починаючи з ранніх термінів і досягаючи максимуму на 20-24-й тиждень вагітності [4, 5]. У першій половині вагітності серцевий викид (СВ) збільшується за рахунок зростання ударного об'єму серця (УОС), у другій половині - за рахунок підвищення частоти серцевих скорочень (ЧСС) $[5,6]$. Збільшення ХОК пояснюють дією на міокард плацентарних гормонів і, частково, як наслідок формування матково-плацентарного кола кровообігу $[1,3]$. Ці зміни спрямовані на забезпечення необхідної для плода інтенсивної доставки кисню [7]. 3 боку системи крові відмічають збільшення ОП та відносне зниження об'єму еритроцитів $(\mathrm{OE})$, що також може бути обумовлено зміною кількості еритропоетину, хоріонічного гонадотропіну та плацентарного лактогену [8]. Впродовж останніх двох триместрів вагітності відмічають збільшення загального об'єму рідини (3ОР) організму [9], проте $\epsilon$ лише поодинокі роботи, в яких вивчали зміни об'ємів водних секторів при прееклампсії.

Мета - дослідити зміни параметрів центральної та периферичної гемодинаміки, а також показників об'ємів водних секторів організму в період вагітності, ускладненої прееклампсією.

\section{Об'єкт і методи дослідження}

Дослідження проведено на базі відділення анестезіології та інтенсивної терапії акушерського стаціонару комунального підприємства «Дніпропетровський обласний перинатальний центр зі стаціонаром» Дніпропетровської обласної ради». У дослідження включено 120 жінок: у 1-шу контрольну групу (n=30) - здорових невагітних жінок фертильного віку, у 2-гу контрольну групу $(n=30)$ - вагітних з неускладненою вагітністю терміном 34-40 тиж, в 3-тю основну групу $(n=60)-$ жінок, вагітність яких ускладнена прееклампсією середнього та тяжкого ступеня.
Критерії включення у дослідження: вік 18-40 років, одноплідна вагітність терміном 34-40 тиж, прееклампсія середнього та тяжкого ступеня, згода на участь у дослідженні.

Критерії виключення з дослідження: вагітні віком <18 та $>40$ років, термін вагітності <34 тиж, багатоплідна вагітність, супутня соматична патологія (цукровий діабет, захворювання серцево-судинної системи, гіпертонічна хвороба, патологія печінки до вагітності), відмова від участі у дослідженні.

Методом неінвазивної біоімпедансометрії комплексом моніторингу кардіореспіраторної системи і гідратації тканин КМ-АР-01 «Діамант» проводили оцінку стану центральної та периферичної гемодинаміки. Визначали $\mathrm{CB}$, серцевий індекс (CI), УОС, ударний індекс (УІ), загальний периферичний опір судин (3ПОС), а також показники водних секторів організму: 3ОР, об'єм внутрішньоклітинної рідини (ОВР), об'єм позаклітинної рідини (ОПР), об'єм крові (ОК), ОП, ОЕ. Виходячи з базової фізіології розподілу рідини, об'єм інтерстицію (ОІ) розраховували за формулою [10]:

$$
\text { OI=OПP-OK. }
$$

Тип гемодинаміки у вагітних визначали за класифікацією Д.В. Садчикова та Д.В. Елютіна (2001) [4]:

1. Еукінетичний: СІ в нормі $\left(2,5-4,0 л / х в \cdot \mathbf{M}^{2}\right)$, 3ПОС у нормі (1200-1500 дин $\left.\cdot \mathrm{C} \cdot \mathrm{CM}^{-5}\right)$.

2. Гіперкінетичний:

- істинна гіперкінезія: $\mathrm{Cl}>4,0$ л/хв· $\mathrm{M}^{2}$, 3ПОС >1500 дин $\cdot \mathrm{C} \cdot \mathrm{CM}^{-5}$;

- ізольована гіпертензія: СІ в нормі $\left(2,5-4,0\right.$ л/хв $\left.\mathrm{M}^{2}\right), 3 П О С$ $>1500$ дин $\cdot \mathrm{C}^{\circ} \mathrm{CM}^{-5}$, систолічний артеріальний тиск (САТ) у нормі, діастолічний артеріальний тиск (ДАТ) підвищений;

- ізольована гіпердинамія: $\mathrm{Cl}>4,0$ л/хв· М² $^{2}$ 3ПОС у нормі (12001500 дин $\left.\cdot \mathrm{C}^{\circ} \mathrm{CM}^{-5}\right)$, переважно підвищений САТ.

3. Гіпокінетичний:

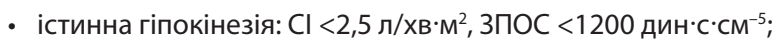

- ізольована гіподинамія: $\mathrm{Cl}<2,5$ л/Хв· $\mathrm{M}^{2}$, 3ПОС у нормі (12001500 дин $\left.\cdot \mathrm{C}^{\circ} \mathrm{CM}^{-5}\right)$;

- ізольована гіпотензія: $\mathrm{Cl}$ в нормі $\left(2,5-4,0\right.$ л/хв $\left.\mathrm{M}^{2}\right), 3 П О С$ $<1200$ дин $\cdot \mathrm{C} \cdot \mathrm{CM}^{-5}$.

4. Дисоціативний:

- гіпотензивно-гіпердинамічний: $\mathrm{Cl}>4,0$ л/хв· $\mathrm{M}^{2}$, 3ПОС $<1200$ дин $\cdot \mathrm{C}^{\circ} \mathrm{CM}^{-5}$; 
- гіпертензивно-гіподинамічний: $\mathrm{Cl} \quad<2,5$ л/хв· $\mathbf{M}^{2}, \quad$ ЗПОС $>1500$ дин $\cdot \mathrm{C} \cdot \mathrm{CM}^{-5}$.

Результати наведено у вигляді середнього арифметичного (М) та його стандартної похибки $(\mathrm{m})$ для певної вибірки (n). t-Критерій Стьюдента використовували для статистичного порівняння. Відмінності вважали статистично достовірними при $\mathrm{p}<0,05$.

\section{Результати}

Аналіз показників центральної та периферичної гемодинаміки невагітних (1-ша контрольна група) та вагітних з неускладненою вагітністю (2-га контрольна група) свідчить про схильність останніх до підвищення рівня як САТ, так і ДАТ (табл. 1).

Так, порівняно з невагітними у вагітних цієї групи САТ був вищим на $7,1 \%$ і становив $115,33 \pm 2,42$ мм рт. Ст., ДАТ — на 5,9\%

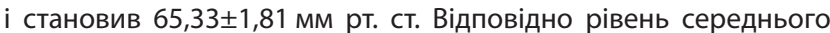
AT (АТсер) теж був вищим - 82,67 $\pm 2,41$ мм рт. ст. Жінки 3 нормальним перебігом вагітності мали тенденцію до підвищення ЧСС $(82,67 \pm 2,41$ уд./хв). Суттєві достовірні зміни виявлені за показником $3 П О С-$ у вагітних він на $25 \%(p<0,05)$ перевищував рівень у невагітних. $\mathrm{Cl}$, навпаки, у вагітних з неускладненою вагітністю достовірно знижувався на $10,7 \%(\mathrm{p}<0,05)$ і стано-

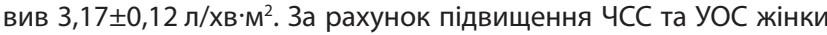
з нормальним перебігом вагітності мали достовірно вищий показник XOK, який перевищував цей самий показник у невагітних на $12,3 \%(p<0,001)$.

Для вивчення змін показників гемодинаміки, які формувалися під впливом вагітності, ускладненої прееклампсією, показники гемодинаміки вагітних з нормальним перебігом вагітності прийнято за норму.

Аналіз показав, що для вагітних з прееклампсією характерне подальше достовірне підвищення САТ на $37,4 \%(p<0,001)$ та ДАТ - на 54,4\% ( $<<0,001)$ порівняно з неускладненою вагітністю. Рівень АТсер у на фоні прееклампсії також на 45,5\% ( $<<0,001)$ перевищував норму й становив 120,25 $\pm 1,85$ мм рт. ст. Аналогічну тенденцію виявлено щодо показника ЧСС. У вагітних 3 прееклампсією він був достовірно вищим на $15,5 \%(p<0,05)$ порівняно з нормальним перебігом вагітності $(88,13 \pm 2,11$ проти $76,33 \pm 2,01$ уд./хв). Ключовими показниками, які визначають тип гемодинаміки при вагітності, $\epsilon \mathrm{Cl}$ та 3ПОС [4]. Вплив прееклампсії яскраво демонструє порівняння вказаних параметрів у вагітних з нормальним перебігом вагітності та з вагітністю, ускладненою прееклампсією. Так, ЗПОС в основній групі становив $2377,09 \pm 66,2$ дин.c $c^{-c}{ }^{-5}$, що на $75,7 \%(p<0,001)$ перевищувало цей показник на фоні неускладненої вагітності. СІ в групі пацієн-

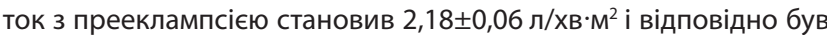
достовірно нижчим на $45,4 \%(p<0,001)$ проти цього показника при неускладненій вагітності. Виражену тенденцію до зниження у пацієнток з прееклампсією мали такі взаємопов'язані показники, як УІ, УОС та ХОК. Так, показник УІ в основній групі знижувався до $34,9 \pm 0,87$ мл/ $\mathrm{M}^{2}$, тобто на $33 \%(p<0,001)$ порівняно з нормою. УОС у вагітних з прееклампсією був також достовірно нижчим

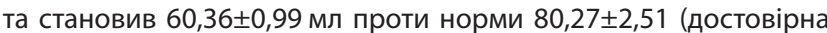
різниця у $33 \%$ ). У тому числі за рахунок цих змін ХОК в основній групі був нижчим на $15,2 \%(p<0,001)$ порівняно з аналогічним параметром гемодинаміки у вагітних з неускладненим перебігом вагітності.

Аналіз показників водних секторів невагітних жінок (1-ша контрольна група) та вагітних з нормальним перебігом вагітності (2-га контрольна група) показав, що 3ОР в організмі останніх

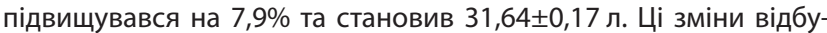
валися за рахунок рівномірного зростання як внутрішньоклітинного, так і позаклітинного секторів (табл. 2).

Достовірних змін при порівнянні показника ОК у цих групах не виявлено. Але тенденцію до підвищення мав плазмовий сектор (ОП) у групі жінок з нормальним перебігом вагітності.

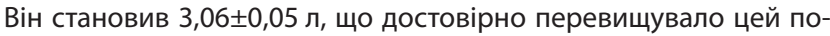
казник на $12,5 \%(p<0,001)$ порівняно 3 невагітними жінками $(2,72 \pm 0,04$ л). Зміни параметру ОЕ були протилежними, тобто

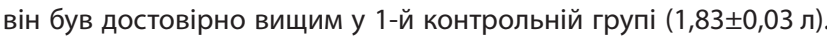

Таблиця 1 Показники центральної та периферичної гемодинаміки у обстежених пацієнток

\begin{tabular}{|c|c|c|c|c|}
\hline Показник & $\begin{array}{c}\text { 1-ша } \\
\text { контрольна } \\
\text { група }\end{array}$ & $\begin{array}{c}\text { 2-га } \\
\text { контрольна } \\
\text { група }\end{array}$ & Основна група & $\mathbf{p}$ \\
\hline САТ, мм рт. ст. & $107,67 \pm 2,06$ & $115,33 \pm 2,42$ & $158,41 \pm 2,81$ & $<0,05<0,001^{*}$ \\
\hline ДАТ, мм рт. ст. & $61,67 \pm 2,39$ & $65,33 \pm 1,81$ & $100,88 \pm 2,57$ & $0,23<0,001^{*}$ \\
\hline ATcep, мм рт. ст. & $77,07 \pm 2,34$ & $82,67 \pm 2,41$ & $120,25 \pm 1,85$ & $0,1<0,001^{*}$ \\
\hline ЧСС, уд./хв & $69,73 \pm 2,06$ & $76,33 \pm 2,01$ & $88,13 \pm 2,11$ & $<0,05<0,001^{*}$ \\
\hline 3ПОС, дин $\cdot \mathrm{C}^{\circ} \mathrm{CM}^{-5}$ & $1082,87 \pm 47,86$ & $1353,2 \pm 47,2$ & $2377,09 \pm 66,2$ & $<0,001<0,001^{*}$ \\
\hline $\mathrm{Cl}, \pi / \mathrm{xB} \cdot \mathrm{M}^{2}$ & $3,55 \pm 0,13$ & $3,17 \pm 0,12$ & $2,18 \pm 0,06$ & $<0,05<0,001^{*}$ \\
\hline $\mathrm{yl}, \mathrm{мл} / \mathrm{m}^{2}$ & $45,25 \pm 0,47$ & $46,4 \pm 0,64$ & $34,9 \pm 0,87$ & $0,15<0,001^{*}$ \\
\hline УОс, мл & $78,29 \pm 1,79$ & $80,27 \pm 2,51$ & $60,36 \pm 0,99$ & $0,52<0,001^{*}$ \\
\hline ХОК, л/Хв & $5,46 \pm 0,09$ & $6,13 \pm 0,14$ & $5,32 \pm 0,09$ & $0,28<0,001^{*}$ \\
\hline
\end{tabular}

АТсер — середній артеріальний тиск; р — достовірність різниці 1-ї та 2-ї контрольних груп; $p^{*}$ — достовірність різниці 2-ї контрольної та основної групи.

Таблиця 2 Показники об'ємів водних секторів у обстежених пацієнTOK

\begin{tabular}{|c|c|c|c|c|}
\hline Показник & $\begin{array}{c}\text { 1-ша } \\
\text { контрольна } \\
\text { група }\end{array}$ & $\begin{array}{c}\text { 2-га } \\
\text { контрольна } \\
\text { група }\end{array}$ & Основна група & $\mathbf{p}$ \\
\hline $30 \mathrm{P}, \pi$ & $29,33 \pm 0,23$ & $31,64 \pm 0,17$ & $35,48 \pm 0,23$ & $<0,001<0,001^{*}$ \\
\hline $\mathrm{OBP}, \pi$ & $19,16 \pm 0,13$ & $20,51 \pm 0,12$ & $21,76 \pm 0,21$ & $<0,001<0,001^{*}$ \\
\hline ОПР, л & $10,17 \pm 0,17$ & $11,13 \pm 0,14$ & $13,72 \pm 0,19$ & $<0,001<0,001^{*}$ \\
\hline OK, л & $4,55 \pm 0,09$ & $4,62 \pm 0,08$ & $4,96 \pm 0,06$ & $0,56<0,05^{*}$ \\
\hline ОП, л & $2,72 \pm 0,04$ & $3,06 \pm 0,05$ & $3,68 \pm 0,09$ & $<0,001<0,001^{*}$ \\
\hline $\mathrm{OE}, \pi$ & $1,83 \pm 0,03$ & $1,56 \pm 0,04$ & $1,28 \pm 0,05$ & $<0,001<0,001^{*}$ \\
\hline $01, \pi$ & $5,62 \pm 0,16$ & $6,51 \pm 0,17$ & $8,76 \pm 0,22$ & $<0,001<0,001^{*}$ \\
\hline
\end{tabular}

р — достовірність різниці 1-ї та 2-ї контрольних груп.

₹* — достовірність різниці 2-ї контрольної групи та основної групи.

Найбільш виражені зміни можна було виявити за показником OI. У вагітних з нормальним перебігом вагітності ОІ перевищував на $15,8 \%(p<0,001)$ цей показник у невагітних і становив $6,51 \pm 0,17$ л.

Аналіз впливу вагітності, ускладненої прееклампсією, на водні сектори організму показав, що ЗОР у групі пацієнтів

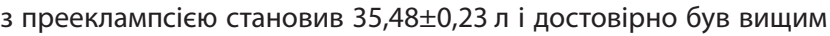
на $12,1 \%(p<0,001)$, ніж у вагітних 3 неускладненою вагітністю (нормою). Але ключову роль в цих змінах відігравало саме збільшення об'єму позаклітинного сектору. Він достовірно перевищував норму на 23,3\% ( $p<0,001)$. При цьому внутрішньоклітинний сектор збільшувався лише на $6,1 \%(p<0,001)$ порівняно з неускладненою вагітністю. ОК у групі вагітних з прееклампсією

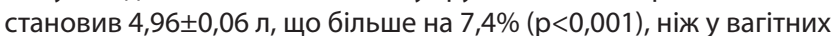
з неускладненою вагітністю. При цьому показник ОП достовірно зростав, а ОЕ достовірно знижувався порівняно з нормою. Найбільш наочну різницю відмічено в динаміці показника ОІ. У вагітних з прееклампсією він збільшився на 34,6\% (p<0,001) і становив 8,76 0,22 л порівняно з групою пацієнтів з нормальним перебігом вагітності.

\section{Обговорення}

Таким чином, перебудова системи кровообігу при нормальному перебігу вагітності полягає у збільшенні ОЦК на фоні підвищення ємності судинного русла й продуктивності серця, коли зростає СВ. Ці зміни забезпечують більш високий рівень роботи різних систем матері, що відповідає зростаючим енергетичним і метаболічним потребам плода. За класифікацією Д.В. Садчикова та Д.В. Елютіна (2001), група вагітних з нормальним перебігом вагітності мала еукінетичний тип кровообігу [4].

Визначення типу гемодинаміки має важливе значення в оцінці функціонального стану кровообігу у вагітних з прееклампсією, що дозволяє отримати додаткову об'єктивну інформацію про динаміку лікування та обґрунтувати вибір терміну та методу розродження. Під впливом прееклампсії формується дисоціа- 
тивний тип кровообігу (гіпертензивно-гіподинамічний), для якого характерні низькі показники СІ та високі значення ЗПОС.

Цей тип кровообігу свідчить про формування порушень материнської кардіоваскулярної адаптації у вигляді спазму судин мікроциркуляторного русла. На фоні зниженого Сl та високого ЗПОС підвищується навантаження на серцевий м'яз. Це призводить до перерозподілу рідини в організмі з розвитком гіповолемії в руслі та гіперволемії в інтерстиції (набряковий синдром). Вказані процеси створюють загрозу виникнення синдрому гіпоперфузії.

\section{Висновки}

1. Для неускладненої вагітності характерні еукінетичний тип гемодинаміки, помірне збільшення 3ОР за рахунок рівномірного зростання як внутрішньо-, так і позаклітинного секторів.

2. Прееклампсія формує дисоціативний тип кровообігу (гіпертензивно-гіподинамічний), на фоні якого порушується перерозподіл рідини між внутрішньо- та позаклітинним секторами за рахунок зменшення ОЦК та збільшення ОІ (набряковий синдром).

Конфлікт інтересів: відсутній.

Conflict of interests: the authors declare no conflict of interests.

Список використаної літератури/References:

1. Zaporozhyan V.M., Mishchenko V.P. (2005) Obstetric Pathology: Atlas. Teaching manual. Odessa, OSMU, 292 p. (In Ukr.).

2. Ostafiychuk S.0. (2019) Bioimpedance analysis of aquatic sectors in pregnant women with hypertensive disorders. Bull. Probl. Biol. Med., 4(1)(153): 134-138. (In Ukr.).

3. Ministry of Health of Ukraine (2011) Order of the Ministry of Health of Ukraine dated 15.07.2011 p. № 417 «About the organization of outpatient obstetric and gynecological care in Ukraine» (https://zakon.rada.gov.ua/rada/show/v0417282-11\#Text). (In Ukr.).

4. Sadchikov D.V., Elyutin D.V. (2001) Systematization of hemodynamic disorders in pregnant women with preeclampsia. Bull. Int. Care, 2: 55-58. (In Rus.).

5. Basevi V., Lavender T. (2017) Routine perineal shaving on admission in labour. The Cochrane Database of Systematic Reviews, Issue 1.

6. Albers L.L., Sedler K.D., Bedric E.J. et al. (2015) Midwifery Care Measures in the Second Stage of Labor and Reduction of Genital Tract Trauma at Birth: A Randomized Trial. J. Midwifery Womens Health, 51(5): 365-372.

\section{Відомості про авторів:}

Клигуненко Олена Миколаївна - доктор медичних наук, професор кафедри анестезіології, інтенсивної терапії та медицини невідкладних станів факультету післядипломної освіти Дніпровського державного медичного університету, Дніпро, Україна. Google Scholar ID: scholar.google.com.ua/citations?user=Lq|3xwQAAAAJ\&hl=ru

Марзан Олександр Олександрович — аспірант кафедри анестезіології, інтенсивної терапії та медицини невідкладних станів факультету післядипломної освіти Дніпровського державного медичного університету, Дніпро, Україна.

Адреса для кореспонденції:

Марзан Олександр Олександрович

49044, Дніпро, вул. Володимира Вернадського, 9

E-mail: ol.marzan@gmail.com
7. Berlit S., Tuschy B., Stojakowits M. et al. (2013) Bioelectrical Impedance Analysis in Pregnancy: Reference Ranges. In Vivo, 27: 851-854.

8. Mancia G., Fagard R., Narkiewicz K. et al. (2013) 2013 ESH/ESC Guidelines for the management of arterial hypertension. J. Hypertension., 31(7): 1281-1357.

9. Staelens A.S., Vonck S., Molenberghs G. et al. (2016) Maternal body fluid composition in uncomplicated pregnancies and preeclampsia: a bioelectrical impedance analysis. Eur. J. Obst. Gynecol. Reproduct. Biol., 204: 69-73.

10. Guyton A.C., Hall J.E. (2006) Textbook of Medical Physiology. 11th ed. Philadelphia, 1091 p.

\section{The influence of pregnancy that is complicated by preeclampsia on the main parameters of central and peripheral hemodynamics and body water compartments volume}

\section{O.M. Klygunenko, O.O. Marzan}

Dnipro State Medical University, Dnipro, Ukraine

Abstract. In the article, it is studied the influence of pregnancy that is complicated by preeclampsia on the main parameters of central and peripheral hemodynamics and body water compartments volume in contrast to healthy pregnancy. 120 women were involved in the research. There were three groups among them: non-pregnant healthy women of fertile age; pregnant women with healthy pregnancy of 34-40 weeks; women whose pregnancy was complicated by mild or severe preeclampsia. Non-invasive bioimpedancemetry with a complex of monitoring of the cardio-respiratory system and tissue hydration was applied to assess central and peripheral hemodynamics and body water compartments index. The study showed that healthy pregnancy is characterized by an eukinetic type of hemodynamics, a moderate increase in total fluid volume. In the meantime, preeclampsia causes a dissociative type of blood circulation against which there is fluid redistribution failure with the development of edema.

Key words: pregnancy, preeclampsia, hemodynamics, body water compartments.

\section{Information about the authors:}

Klygunenko Olena M. - Doctor of medical sciences, Professor of the Department of anesthesiology, intensive care and medical emergency of the Faculty of Postgraduate Education, Dnipro State Medical University, Dnipro, Ukraine. Google Scholar ID: scholar.google.com.ua/citations?user=L ql3xwQAAAAJ\&hl=ru

Marzan Olexander 0. - graduate student of the Department of anesthesiology, intensive care and medical emergency of the Faculty of Postgraduate Education, Dnipro State Medical University, Dnipro, Ukraine.

Address for correspondence:

Olexander Marzan

49044, Dnipro, Vernadsky str., 9

E-mail: ol.marzan@gmail.com 